\title{
EFFECT OF METHOXYFLURANE ON EPINEPHRINE-INDUCED VENTRICULAR ARRHYTHMIAS
}

\author{
Bruce W. Burleigh, m.D., and Nicholas M. Greene, m.D.*
}

THE EFFECT OF METHOXYfluRANe on the sensitivity of the heart to epinephrineinduced ventricular arrhythmias has not been clearly defined. On the one hand, animal experiments have been reported which found that methoxyflurane increases ventricular arrhythmias associated with epinephrine administration. ${ }^{1,2}$ On the other hand, other studies have found that methoxyflurane protects against arrhythmias. ${ }^{3,4}$ Still other reports have found methoxyflurane to be less sensitizing than cyclopropane or halothane, but as sensitizing as chloroform or halothaneether azeotrope. ${ }^{5,6}$ That epinephrine can be safely injected subcutaneously to secure haemostatis during operations performed under methoxyflurane ${ }^{7-15}$ is a unanimous if pragmatic observation. It is an observation, however, which neither defines the risk, if any, involved in such a practice, nor contributes to our understanding of the pharmacological properties of methoxyflurane.

The present study was undertaken to evaluate under controlled conditions in experimental animals (1) the effect of methoxyflurane on ventricular sensitivity to epinephrine-induced arrhythmias, and (2) the effect of methoxyflurane on severity of ventricular arrhythmias produced by epinephrine. The former was determined by measuring the effect of methoxyflurane on the time required for appearance of ventricular arrhythmias during the continuous infusion of a standard, dilute solution of epinephrine. The latter was measured as the effect of methoxyflurane on duration of ventricular arrhythmias produced by epinephrine. Duration of ventricular arrhythmias was equated with severity on the basis that one or two abnormal ventricular contractions are not of the same significance as well established, continuing abnormal contractions.

\section{METHODS}

Nine unanaesthetized, unmedicated mongrel dogs weighing between 12.5 and $22.5 \mathrm{~kg}$ were paralysed with succinylcholine to permit insertion of cuffed endotracheal tubes. Respirations were controlled by a non-rebreathing constant volume respirator set to deliver $4 \mathrm{~L} / \mathrm{min}$ of 100 per cent oxygen. A thin-walled 16 gauge needle was inserted into an external jugular vein of each dog and a dilute ( 1 $\mathrm{mg} / \mathrm{ml}$ ) solution of succinylcholine was infused at the rate of $1 \mathrm{mg} / \mathrm{min}$ to main-

${ }^{\circ}$ Dr. Burleigh was a medical student research fellow while carrying out this research. Dr. Greene is professor of anesthesiology at the Division of Anesthesiology, Yale University School of Medicine, and the Department of Anesthesiology, Yale New Haven Medical Center, New Haven, Connecticut. Address reprint requests to Dr. Nicholas M. Greene, 789 Howard Ave., New Haven, Conn. 06504. 
tain paralysis. A plastic intravenous tube was used to connect a $20 \mathrm{ml}$ syringe containing a dilute epinephrine solution $(0.1 \mathrm{mg} / \mathrm{ml})$ to the distal end of the succinylcholine infusion tubing. The syringe was placed in a pump, set to deliver $1.0 \mathrm{ml} / \mathrm{min}$ when turned on.

Electrocardiogram needles were inserted into the right forepaw and the left hind leg. A Grass Polygraph was used to record standard lead 2 ECG tracings from these at a paper speed of $250 \mathrm{~cm} / \mathrm{min}$.

Each dog was allowed to stabilize until ECG tracings showed only normal sinus rhythm for at least $15 \mathrm{~min}$ as determined by ECG monitoring. The experiment thereafter was divided into two parts, with each animal serving as its own control.

Part one consisted of infusion of epinephrine into the paralysed but unanaesthetized dog using a technique similar to that of Meek et al., ${ }^{16}$ but at a rate of $0.1 \mathrm{mg} / \mathrm{min}$ while the ECG was continuously monitored. The infusion was continued until a ventricular arrhythmia appeared (premature ventricular contraction, ventricular tachycardia, or ventricular fibrillation). The infusion was then immediately stopped but the ECG recording continued until regular sinus rhythm was restored. Time of onset of ventricular arrhythmias was defined as the interval between initiation of the epinephrine infusion and appearance of the first ventri-

TABLE I

\begin{tabular}{|c|c|c|}
\hline Dog & $\begin{array}{l}\text { Part one: } \\
\text { epinephrine infusion in } \\
\text { conscious animals }\end{array}$ & $\begin{array}{l}\text { Part two: } \\
\text { epinephrine infusion during } \\
1 \% \text { methoxyflurane }\end{array}$ \\
\hline 1 & $\begin{array}{l}\text { premature ventricular } \\
\text { contractions and atrio- } \\
\text { ventricular dissociation }\end{array}$ & $\begin{array}{l}\text { premature ventricular } \\
\text { contractions and atrio- } \\
\text { ventricular dissociation }\end{array}$ \\
\hline 2 & $\begin{array}{l}\text { premature ventricular } \\
\text { contractions }\end{array}$ & $\begin{array}{l}\text { premature ventricular } \\
\text { contractions }\end{array}$ \\
\hline 3 & $\begin{array}{l}\text { premature ventricular } \\
\text { contractions and atrio- } \\
\text { ventricular dissociation }\end{array}$ & $\begin{array}{l}\text { premature ventricular } \\
\text { contractions }\end{array}$ \\
\hline 4 & $\begin{array}{l}\text { premature ventricular } \\
\text { contractions with } \\
\text { bigeminy and trigeminy }\end{array}$ & $\begin{array}{l}\text { premature ventricular } \\
\text { contractions }\end{array}$ \\
\hline 5 & $\begin{array}{l}\text { premature ventricular } \\
\text { contractions }\end{array}$ & $\begin{array}{l}\text { premature ventricular } \\
\text { contractions - aberrant } \\
\text { conduction }\end{array}$ \\
\hline 6 & $\begin{array}{l}\text { premature ventricular } \\
\text { contractions - atrio- } \\
\text { ventricular dissociation and } \\
\text { aberrant conduction }\end{array}$ & $\begin{array}{l}\text { premature ventricular } \\
\text { contractions }\end{array}$ \\
\hline 7 & $\begin{array}{l}\text { premature ventricular } \\
\text { contractions - aberrant } \\
\text { conduction }\end{array}$ & $\begin{array}{l}\text { premature ventricular } \\
\text { contractions }\end{array}$ \\
\hline 8 & $\begin{array}{l}\text { premature ventricular } \\
\text { contractions - ventricular } \\
\text { tachycardia at } 464 \text { per minute }\end{array}$ & $\begin{array}{l}\text { premature ventricular } \\
\text { contractions with } \\
\text { aberrant conduction }\end{array}$ \\
\hline 9 & $\begin{array}{l}\text { premature ventricular } \\
\text { contractions - atrio- } \\
\text { ventricular dissociation } \\
\text { and aberrant conduction }\end{array}$ & $\begin{array}{l}\text { premature ventricular } \\
\text { contractions }\end{array}$ \\
\hline
\end{tabular}


cular arrhythmia; duration of arrhythmia as the interval between appearance of first ventricular arrhythmia and restoration of regular sinus rhythm.

A period of 30 minutes was allowed for inactivation of infused epinephrine ${ }^{17}$ before proceeding to part two of the experiment. Part two consisted of introducing between the oxygen supply and the respirator a constant temperature (Pentec) vaporizer set to deliver 1.0 per cent methoxyllurane. After methoxyflurane had been administered for 25 minutes, the epinephrine infusion was again started at the rate of $0.1 \mathrm{mg} / \mathrm{min}$ and allowed to continue with continuous ECc monitoring until the first ventricular arrhythmia appeared. The infusion was then stopped and the ECG continued until sinus rhythm was re-established. Time of onset and duration of arrhythmias were determined as in part one. Because of the long duration of action of methoxyflurane the sequence of the experiments was not reversed.

Differences in time of onset and duration of arrhythmias between parts one and two were analysed using Student's $t$-test, statistical significance being assumed when $p$ values were 0.05 or less.

\section{Results}

The types of arrhythmia produced are summarized in Table I, time of onset in Table II, and duration in Table III. The most frequent arrhythmias were premature ventricular contractions, often multifocal. Mean time of onset was $39.1 \pm 4.0$ sec in the absence of methoxyflurane, $54.2 \pm 7.4 \mathrm{sec}$ in the presence of methoxyflurane. The difference in time of onset was not statistically significant.

TABLE II

Time of Onset of the Ventricular Arrhythmias

\begin{tabular}{lcc}
\hline Dog & $\begin{array}{c}\text { Epinephrine infusion in } \\
\text { conscious animals (sec) }\end{array}$ & $\begin{array}{c}\text { Epinephrine infusion during } \\
\text { 1\% methoxyflurane (sec) }\end{array}$ \\
\hline 1 & 41.1 & 51.8 \\
2 & 21.9 & 42.6 \\
3 & 32.4 & 62.7 \\
4 & 29.6 & 33.7 \\
5 & 42.6 & 88.4 \\
6 & 50.0 & 51.1 \\
7 & 59.6 & 41.1 \\
8 & 28.2 & 27.0 \\
9 & 46.7 & 89.6 \\
Mean & 39.1 & 54.2 \\
Standard error & & \\
of the mean & \pm 4.04 & \pm 7.42 \\
\hline$t$ value: 2.03. & &
\end{tabular}

Duration of ventricular arrhythmias averaged $38.7 \pm 4.1 \mathrm{sec}$. in the unanaesthetized and $29.2 \pm 11.6 \mathrm{sec}$. in the anaesthetized dogs. Again, the difference was not statistically significant. 
TABLE III

Duration of the Ventricular ARrhythmias

\begin{tabular}{lcc}
\hline \hline Dog & $\begin{array}{c}\text { Epinephrine infusion in } \\
\text { conscious animals (sec) }\end{array}$ & $\begin{array}{c}\text { Epinephrine infusion during } \\
\text { 1\% methoxyflurane (sec) }\end{array}$ \\
\hline 1 & 27.2 & 43.2 \\
2 & 27.8 & 9.4 \\
3 & 44.0 & 18.0 \\
4 & 38.9 & 49.9 \\
5 & 39.2 & 0.3 \\
6 & 51.6 & 0.6 \\
7 & 50.9 & 0.6 \\
8 & 51.5 & 7.4 \\
9 & 17.4 & 29.2 \\
Mean & 38.7 & \\
Standard error & & \pm 11.63 \\
of the mean & \pm 4.12 & \\
\hline
\end{tabular}

$t$ value: 0.82

\section{Discussion}

Previous studies of the effect of methoxyflurane on sensitivity of the heart to epinephrine-induced ventricular arrhythmias have been concerned either with comparisons made between the effect of methoxyflurane and the effect of other inhalation anaesthetics, ${ }^{1,4-6}$ or with the effect of methoxyflurane on the response to single intravenous injections of epinephrine. ${ }^{6,18}$ The former studies give important comparative data but do not define the effect of methoxyflurane per se. The latter by relying upon the single injection of a standard amount of epinephrine make the determination of sensitivity thresholds in individual animals impossible because the amount of epinephrine injected may be in excess of the minimum amount required to produce an arrhythmic effect. The present study permits evaluation of the effect of methoxyflurane by comparing the response to epinephrine under only two conditions: in the presence and absence of methoxyflurane. It also permits determination of the effect of methoxyflurane on sensitivity thresholds to the arrhythmic effect of epinephrine by using each dog as its own control and by continuously infusing dilute epinephrine at a constant rate in the presence and absence of methoxyflurane until arrhythmias are produced. Further, it is the only report of the effect of methoxyflurane on duration of ventricular arrhythmias produced by epinephrine.

The results of our investigation indicate that methoxyflurane has no significant effect either on the sensitivity of the canine heart to epinephrine or on the duration of epinephrine-induced arrhythmias. Methoxyflurane, therefore, neither protects the heart from the arrhythmic effect of epinephrine nor sensitizes it to the drug. These results agree with the laboratory findings of Van Poznak and Artusio ${ }^{3}$ as well as with the uncontrolled clinical studies reported by others. ${ }^{7-15}$

On the basis of the present data, methoxyflurane is the inhalation anaesthetic of choice when epinephrine is to be used either by subcutaneous injection to achieve local haemostasis or by intravenous infusion to support a failing heart by virtue of its positive inotropic and chronotropic effect. This is in contrast to tri- 
chlorethylene and halothane anaesthesia, when intravenous epinephrine is contraindicated and when subcutaneous injections are recommended only in very dilute solutions. ${ }^{19,20}$ It is also in contrast to cyclopropane anaesthesia, when epinephrine is contraindicated in any amount by any route. ${ }^{21}$

\section{SUMMARY}

Methoxyflurane anaesthesia in dogs had no significant effect on time of onset or duration of ventricular arrhythmias produced by continuous infusion of epinephrine. It is concluded that methoxyflurane neither protects nor sensitizes the canine myocardium to epinephrine. It is suggested that methoxyflurane is the inhalation anaesthetic of choice when epinephrine is employed.

\section{RÉSUMÉ}

L'anesthésie au méthoxyflurane chez les chiens n'a pas eu d'effet appréciable sur le moment du début ou sur la durée des arythmies ventriculaires produites par une infusion continue d'épinéphrine. On peut conclure que le méthoxyflurane ne protège ni ne sensibilise le myocarde des chiens à l'épinéphrine. On est d'avis que, parmi les anesthésiques par inhalations, de méthoxyflurane est l'anesthésique de choix lorsque l'épinéphrine est utilisée.

\section{REFERENCES}

1. Orth, O. S.; Leigh, M. D.; Mellish, C. H.; \& Stutzman, J. W. Action of Sympathomimetic Amines in Cyclopropane, Ether and Chloroform Anesthesia. J. Pharmacol. \& Exper. Therap. 67: 1 (1939).

2. Bamforth, B. J.; Stebecker, K. L.; Kraemer, R.; \& Orth, O. S. Effect of Epinephrine on the Dog Heart during Methoxyflurane Anesthesia. Anesthesiology. 22: 169 (1960).

3. Van Poznak, A. \& Artusio, J. F., Jr. A Series of Fluorinated Ethers. Fed, Proc, 19: 273 (1960).

4. North, W. C. \& KNox, P. R. The Influence of Methoxyflurane upon the Cardiovascular Response to Epinephrine. Fed. Proc. 20: 312 (1961).

5. Dobkin, A. B. \& Israel, J. S. The Effect of SA 97, Perphenazine and Hydroxyzine on Epinephrine-induced Cardiac Arrythmias during Methoxyflurane Anaesthesia in Dogs. Canad. Anaesth. Soc. J. 9: 36 (1962).

6. Israel, J. S.; Criswick, V. G.; \& Dobkin, A. B. Effect of Epinephrine on Cardiac Rhythm during Anesthesia with Methoxyflurane (Penthrane) and Trifluoroethyl Vinyl Ether (Fluoromar). Acta Anaesth. Scandinav. 6: 7 (1962).

7. Hudon, F. Methoxyflurane. Canad. Anaesth. Soc. J. 8: 544 (1961).

8. Andersen, N. \& Andersen, E. W. Methoxyflurane. Acta Anaesth. Scandinav. 5: 179 (1961).

9. Kaveney, R. E. \& W Wsmuth, C. E. Methoxyflurane: A Clinical Evaluation of Its Effects, Based on Five Hundred Cases. Cleveland Clin. Quart. 29: 148 (1962).

10. JAcques, A. \& Hudon, F. Effect of Epinephrine on the Human Heart during MethoxyHurane Anaesthesia. Canad. Anaesth. Soc. J. 10: 53 (1963).

11. McGarry, P. M. F. Clinical Experience with Methoxyflurane (Penthrane). Canad. Anaesth. Soc. J. 10:380 (1963).

12. Jarman, R. \& Edghil, H. B. Methoxyflurane (Penthrane). Anaesthesia. 18: 265 ( 1963 ).

13. Erickson; J. C. m; Krumperman, L. W.; \& Ronis, M. L. Methoxyflurane Anaesthesia for Middle Ear Surgery. Arch. Otolaryngol. 80: 69 (1964).

14. Nonth, W. C. \& Stephen, L. R. A Second Look at Methoxyllurane: Four Years of Experience. Anesth. \& Analg. 45: 117 (1966). 
15. ARENS, J. F. Methoxyflurane and Epinephrine Administered Simultaneously. Anesth. \& Analg. 47: 391 (1968).

16. MEEK, W. J.; Hathaway, H. R.; \& ORTh, O. S. The Effects of Ether, Chloroform and Cyclopropane on Cardiac Automaticity. J. Pharmacol, Exper. Therap. 61: 240 (1937).

17. Cohen, G.; Holland, B.; Sha, J.; \& Goldenderc, M. Plasma Concentrations of Epinephrine and Norepinephrine during Intravenous Infusion in Man. J. Clin. Invest. 38: 1935 (1959).

18. Isratel, J. S.; Dobkin, A. B.; \& Robimoux, H. J. The Effect of Sympathetic Blockade or Hyperventilation on Epinephrine-induced Cardiac Arrythmias during Anaesthesia with Halothane and Methoxyflurane. Canad. Anaesth. Soc. J. 9: 125 (1962).

19. Matteo, R. S.; Katz, R. L.; \& Papper, E. M. The Injection of Epinephrine during General Anesthesia with Halogenated Hydrocarbons and Cyclopropane in Man: I. Trichlorethylene. Anesthesiology. 23: 360 (1962).

20. KA Tz, R. L.; MATTEO, R. S.; \& PApper, E. M. Injection of Epinephrine during General Anesthesia with Halogenated Hydrocarbons and Cyclopropane in Man: II. Halothane. Anesthesiology, 23: 597 (1962).

21. Matteo, R. S.; Katz, R. L.; \& Papper, E. M. Injection of Epinephrine during General Anesthesia with Halogenated Hydrocarbons and Cyclopropane in Man: III. Cyclopropane. Anesthesiology. 24: 327 (1963). 